\title{
STABILITAS EKSTRAK KURKUMIN KUNYIT DAN KLOROFIL DAUN PANDAN MENGGUNAKAN $\alpha$ TOCOFEROL DAN DEKSTRIN
}

\section{Stability of Turmeric's Curcumin Extract and Pandan Leaves's Chlorophyll Using $\alpha$ Tocoferol and Dextrin}

\author{
Elizarni $^{1 *}$, Firdausni ${ }^{2}$, Hazil Anwar ${ }^{3}$, dan Risma Sari ${ }^{4}$ \\ 1,3,4: Program Studi Kimia Analisis, Akademi Teknologi Industri Padang \\ Jalan Bungo Pasang Tabing, Padang. 25171 \\ 2: Baristand Industri Padang Jalan Raya LIK No. 23 Ulu Gadut, Padang. 25164 \\ * e-mail: elizarni187@gmail.com
}

Diterima: 21 Juli 2014, revisi akhir: 3 Desember 2014 dan disetujui untuk diterbitkan: 11 Desember 2014

\begin{abstract}
ABSTRAK
Zat warna alam mempunyai tingkat kestabilan yang rendah dibandingkan pewarna sintetis dalam proses pengolahan, pemanasan, dan penyimpanan, karena pewarna alami mudah mengalami degradasi atau pemudaran. Penelitian ini dilakukan untuk mempelajari pembuatan zat warna alam dalam bentuk bubuk dari bahan baku kunyit dan daun pandan yang memiliki tingkat kestabilan yang baik dalam penggunaannya sebagai bahan tambahan makanan. Tujuan penelitian untuk mendapatkan ekstrak kurkumin dari kunyit dan klorofil dari daun pandan yang optimum dengan variasi pemakaian air panas dan $\mathrm{pH}$. Terhadap ekstrak dilakukan pemakaian $\alpha$ tocoferol dan dekstrin yang optimum untuk mendapatkan bubuk kering dari kunyit dan daun pandan. Hasil penelitian menunjukkan bahwa $\mathrm{pH}$ larutan ekstraksi yang terbaik untuk kunyit adalah $\mathrm{pH} 4$ pada suhu pemanasan $60^{\circ} \mathrm{C}$ dengan nilai absorban 0,8539 , sedangkan untuk $\mathrm{pH}$ optimum ekstraksi klorofil dari daun pandan adalah $\mathrm{pH} 10$ dengan absorban 0,9208. Pemakaian dekstrin $1-3 \%$ dapat meningkatkan kestabilan zat warna.
\end{abstract}

Kata Kunci: Stabilitas warna, kunyit, daun pandan, $\alpha$ Tocoferol, dekstrin

\section{ABSTRACT}

Stability level of natural dyes is lower than synthetic dyes in treatment process, heating, and storage because natural dyes are easy to degrade or fade. The research was conducted to study the natural dyestuff manufacturing in the form of raw turmeric powder and pandan leaves which have a good stability in use as a food additive. The purpose of research was to get the optimum curcumin extract from turmeric and pandan leaves's chlorophyll with variations of hot water used and $\mathrm{pH}$. In the obtaining extract was used optimum tocopherol and dextrins to get a dry powder of turmeric and pandan leaves. The result of research showed that the best $\mathrm{pH}$ solution for the extraction of turmeric was $\mathrm{pH} 4$ at a heating temperature $60^{\circ} \mathrm{C}$ with absorbance value 0.8539 , while the optimum $\mathrm{pH}$ for chlorophyll extraction from pandan leaves was $\mathrm{pH} 10$ with absorbance value 0.9208 . The use of $1-3 \%$ dextrin could increase the stability of the dyes.

Keywords: Colour's stability, turmeric, pandan leaves, $\alpha$ Tocoferol, dextrin

\section{PENDAHULUAN}

Penentuan mutu bahan makanan pada umumnya sangat bergantung pada beberapa faktor diantaranya cita rasa, warna, tekstur dan nilai gizinya. Dewasa ini penggunaan zat warna sudah semakin luas terutama dalam makanan dan minuman, karena warna makanan memberikan daya tarik bagi konsumen. Warna yang mencolok lebih disukai konsumen, terutama anakanak. Hal inilah yang menyebabkan produsen makanan memproduksi makanan dengan warna-warna yang menarik. 
Sayangnya warna tidak berbanding lurus dengan kualitas atau nilai gizi makanan, bahkan berbanding terbalik jika pewarna yang digunakan adalah pewarna makanan sintetis dengan kriteria non food grade colourant atau zat warna yang bukan untuk pewarna makanan.

P e warna makanan dapat diklasifikasikan atas pewarna makanan alami dan pewarna makanan sintetis Pewarna makanan alami sudah dikenal oleh masyarakat Indonesia sejak zaman dahulu, seperti daun suji, kunyit, kesumba dan sebagainya. Bahan alami tersedia dalam jumlah yang berlimpah. Namun penggunaan pewarna makanan alami ditinggalkan produsen makanan karena kurang praktis dalam pemakaiannya terkait dengan belum adanya pewarna alami yang dijual di pasaran sehingga produsen makanan harus membuat sendiri pewarna makanan yang dibutuhkan tersebut. Keterbatasan pewarna alami seringkali memberikan rasa dan flavor khas yang tidak diinginkan, konsentrasi pigmen rendah, stabilitas pigmen rendah, keseragaman warna kurang baik dan spektrum warna tidak seluas pewarna sintetik. Pewarna sintetik mempunyai keuntungan dibandingkan pewarna alami, yaitu mempunyai kekuatan mewarnai yang lebih kuat, lebih seragam, lebih stabil dan biasanya lebih murah (Yoko Wibisono, 2012).

Disamping itu kelemahan dari penggunaan pewarna alami adalah warna yang kurang stabil yang bisa disebabkan oleh perobahan $\mathrm{pH}$, proses oksidasi, pengaruh cahaya dan pemanasan, sehingga intensitas warnanya sering berkurang selama proses pembuatan makanan. Akibatnya produsen makanan banyak yang beralih ke pewarna makanan sintetis. Pewarna makanan sintetis yang dibolehkan harganya cukup mahal sehingga banyak produsen makanan yang menggunakan pewarna tekstil untuk produk dan sangat berbahaya karena bahan ini dapat menyebabkan kanker dan penyakit lainnya.

Jenis pewarna yang sering ditemukan dalam beberapa produk pangan diantaranya Sunset Yellow dan Tartrazine secara komersial digunakan sebagai zat aditif makanan (Pedro cit Winarni, 2008).
Pigmen alami dapat menjadi salah satu pilihan untuk meningkatkan ketahanan dan kualitas pangan karena pigmen alami merupakan salah satu zat non gizi yang mampu memberikan nutrisi bagi tubuh. Selain itu, pigmen alami ditemukan sangat melimpah pada sebagian besar sumber daya alam lokal Indonesia. Pigmen alami juga terbukti aman, baik sebagai makanan maupun pewarna makanan dibandingkan pewarna sintetik. Bahkan penggunaan pigmen alami sebagai pewarna makanan saat ini sedang menjadi perhatian para konsumen dan juga industriawan. Kenyataan ini karena penggunaan pewarna alami lebih menguntungkan dibandingkan pewarna sintetis, yaitu aman karena terbuat dari bahan alam yang tidak menimbulkan efek negatif bagi tubuh, mudah didapat, serta dapat menimbulkan rasa dan aroma khas. Pewarna sintetik dapat berdampak negatif yaitu menyebabkan toksik dan karsinogenik.

Beberapa pigmen alami yang dapat digunakan sebagai pewarna pada makanan adalah klorofil (hijau) pada daun singkong (Titihalawa, 2010) kurkuminoid (kuning) dari curcumin (Niu et al., 2012) karotenoid (orange-merah), antosianin (ungu, biru, merah). Berdasarkan penelitian Melawati (2009) ekstraksi pigmen antosianin paprika merah menggunakan pelarut aquadest dan asam tartarat $1 \%$ menghasilkan total antosianin $0,879 \mathrm{mg} / \mathrm{g}$ dan stabil pada $\mathrm{pH} 2-$ 4. Jenis-jenis pewarna tersebut aman dikonsumsi seperti antosianin kulit manggis (Setyaningrum, 1991) karena tidak mengandung bahan beracun yang berbahaya bagi kesehatan dan tidak mencemari lingkungan seperti pewarna sintetik. Pigmen alami juga memiliki beragam khasiat kesehatan dan telah dimanfaatkan pada beberapa makanan (Limantara dan Rahayu, 2008).

Kandungan utama rimpang kunyit (Curcuma spp) berupa minyak atsiri, curcuminoid termasuk kurkumin, resin, oleoresin, lemak dan protein (Sharma et al, 2005) dan Kristina dkk, 2005. Curcumin merupakan derivat polifenol dari tanaman yang berfungsi sebagai antioksidan pada suasana asam dan $\mathrm{pH}$ netral (Tonnesen, 1991). 
Penggunaan zat warna alam (back to nature) pada masa yang akan datang memerlukan penyediaan zat warna alam dengan bahan baku yang mudah didapat, kemudahan dalam pengambilan zat warna dan yang terpenting mempunyai stabilitas yang baik terhadap suhu dan cahaya pada proses pengolahan dan penyimpanan.

Dalam mempertahankan stabilitas zat warna alam dalam penyimpanan dapat dilakukan dengan mencari bahan untuk menstabilkan zat warna alam seperti penggunaan antioksidan, melapisi zat warna (Gustriyeni dkk, 2008 ; Altunbas, 2011) dan menyimpan dalam wadah yang tahan terhadap suhu dan cahaya.

Antioksidan alami dan antioksidan sintetis BHA (Butylated Hydroxyanisole) telah digunakan untuk pencegahan proses oksidasi pada rendang (Yusmeiarti dkk, 1998). Penggunaan antioksidan sintetis BHA 0,02\% memberikan hasil yang cukup memadai dengan lama penyimpanan 4 minggu memberikan hasil terbaik dari sisi nilai rasa dan bau 5,00 dan 4,98. Dengan pemberian antioksidan yang berbeda konsentrasinya $0,01 \%$ tidak mempengaruhi nilai rasa rendang walaupun nilainya cenderung turun, tapi masih dalam taraf suka (Elizarni et al., 2007).

Penelitian ini diharapkan dapat menghasilkan zat warna alam dari ekstrak kunyit (warna kuning) dan daun pandan yang berwarna hijau. Untuk mempertahankan kestabilan zat warna agar tetap cerah, pembuatan zat warna alam dalam bentuk bubuk dapat ditambahkan antioksidan seperti $\alpha$ tokoferol dan asam askorbat. Penggunaan antioksidan tidak stabil jika digunakan sendiri. Peningkatan stabilitasi bahan dilakukan dengan penambahan bahan pelapis dengan proses mikroenkapsulasi. Penggunaan antioksidan (asam askorbat dan a tokoferol) dan dan pelapis (gelatin, keragenan, dextrin) mempengaruhi kestabilan zat warna terhadap pengaruh panas, UV, oksidator dan kelarutan dalam minyak (Yeni dkk., 2008).

Bahan penstabil yang digunakan dalam penelitian ini adalah dekstrin dan tokoferol yang berfungsi sebagai antioksidan. Penggunaan pelapis dengan sistim mikroenkapsulasi dengan dekstrin merupakan cara penyimpanan zat pewarna yang dihasilkan.
Penelitian akan mendapatkan ekstrak kurkumin dari kunyit dan ekstrak klorofil dari daun pandan yang optimum dengan menggunakan bahan pelapis sehingga didapatkan teknologi yang dapat mempertahankan stabilitas zat warna alam dalam penyimpanan dan pengolahan.

\section{METODOLOGI PENELITIAN}

Bahan utama yang digunakan dalam penelitian ini adalah kunyit, daun pandan dan bahan pembantu proses meliputi gelatin, dekstrin, $\alpha$ tokoferol, kapur sirih, aquades, asam sitrat. Bahan baku kunyit diambil dari kunyit pilihan dengan umur tanaman 11-12 bulan dengan mutu bagus dari Pasar Raya Padang. Bahan baku daun pandan berasal dari daerah Tabing Kota Padang. Peralatan yang digunakan antara lain, kolom maserasi, spray drying, Spektrofotometer UV-VIS, pH meter.

Kegiatan penelitian dilakukan di laboratorium ATIP (Akademi Teknologi Industri Padang), laboratorium Baristand Industri Padang dan Laboratorium Farmasi Universitas Andalas Padang. Rancangan yang digunakan dalam penelitian ini adalah Rancangan Acak Lengkap (RAL) dengan 2 (dua) faktor. Ekstraksi pewarna dengan menggunakan pelarut air pada suhu $40^{\circ} \mathrm{C}$ dan $60^{\circ} \mathrm{C}$ dengan pengaturan $\mathrm{pH}$ larutan 3 , 4, 5, dan 6. Pemakaian antioksidan $\alpha$ tokoferol $1 \%$ dan pelapis dekstrin $0 \%, 1 \%$, $2 \%, 3 \%, 4 \%$ dan $5 \%$.

\section{Pelaksanaan Penelitian}

1. Kurkumin Kunyit

Bahan baku kunyit yang digunakan dalam penelitian disortir, dibersihkan dan dibuang kulit tipisnya kemudian dihaluskan. Dilakukan maserasi menggunakan air panas pada suhu $40^{\circ} \mathrm{C}$ dan suhu $60^{\circ} \mathrm{C}$, dan variasi $\mathrm{pH}$ larutan yaitu $\mathrm{pH} 3,4,5$ dan 6 . Selanjutnya penambahan antioksidan $\alpha$ tokoferol $1 \%$ dan penambahan pelapis dekstrin $(0 \%$, $1 \%, 2 \%, 3 \%, 4 \%, 5 \%$ )

2. Klorofil daun Pandan

Bahan baku daun pandan segar yang digunakan disortir, dipotong dan dihaluskan kemudian diambil ekstraknya dengan cara menyaring. Ekstrak daun 
pandan diperlakukan dengan variasi $\mathrm{pH}$ larutan ekstraksi 4-10 (interval 1 satuan $\mathrm{pH}$ ). Ekstrak ditambahkan dengan antioksidan $\alpha$ tokoferol $1 \%$ dan pelapis dekstrin $(0 \%, 1 \%, 2 \%, 3 \%, 4 \%, 5 \%)$.

Pengamatan fisik dan kimia dilakukan terhadap kestabilan zat warna, pengaruh pemanasan, lama penyimpanan, paparan cahaya matahari dengan menggunakan spektrofotometer pada $665 \mathrm{~nm}$.

\section{HASIL DAN PEMBAHASAN.}

\section{Ekstraksi Kurkumin Kunyit dan Klorofil dari Daun Pandan}

\section{Pengaruh pH larutan dan suhu pada ekstraksi kurkumin dari kunyit}

Ekstraksi kurkumin dari kunyit dan klorofil dari daun pandan dapat dilihat pada Gambar 1 dan 2.

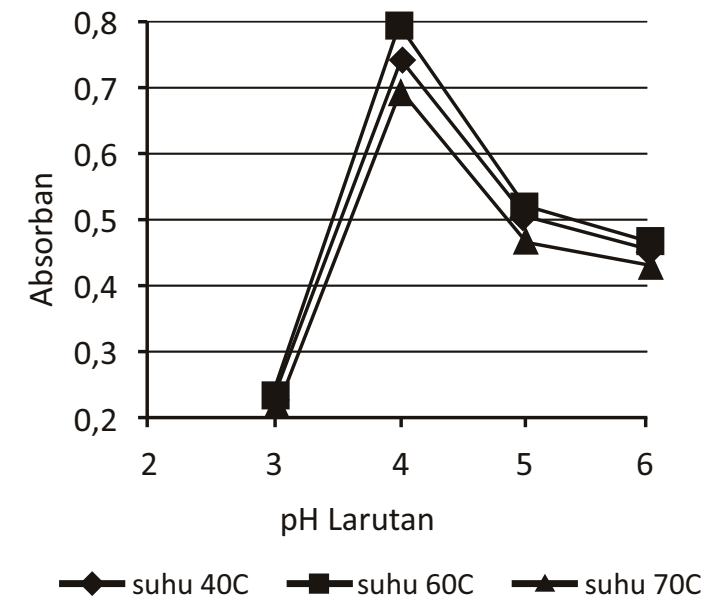

Gambar 1. Pengaruh pH larutan dan suhu pada ekstrak kunyit terhadap absorban (1 g kunyit dan volume larutan $100 \mathrm{~mL}$ )

Pada Gambar 1 terlihat bahwa pada $\mathrm{pH}$ larutan 4 terjadi peningkatan absorban dan $\mathrm{pH}$ larutan ekstraksi terbaik adalah $\mathrm{pH} 4$ dengan suhu pemanasan $60^{\circ} \mathrm{C}$ (nilai Absorban mendekati ekstraksi kurkumin dengan alkohol 0,8539). Pada penelitian Maulana et al, 2012 menyatakan pigmen antosianin pada kelopak rosella lebih stabil dalam keadaan $\mathrm{pH}$ rendah/ asam. Stabilitas optimum kurkumin didapatkan dengan mempertahankan $\mathrm{pH}$ rendah karena $\mathrm{pH}$ lebih dari 7 menyebabkan kurkumin tidak stabil dan mudah terdisosiasi. Metabolit utama curcumin berupa tetra hydro curcumin (THC) dan lebih stabil pada $\mathrm{pH}$ dibawah 7 ( Sharma et al, 2005).

\section{Pengaruh pH larutan dan suhu pada ekstraksi klorofil daun pandan}

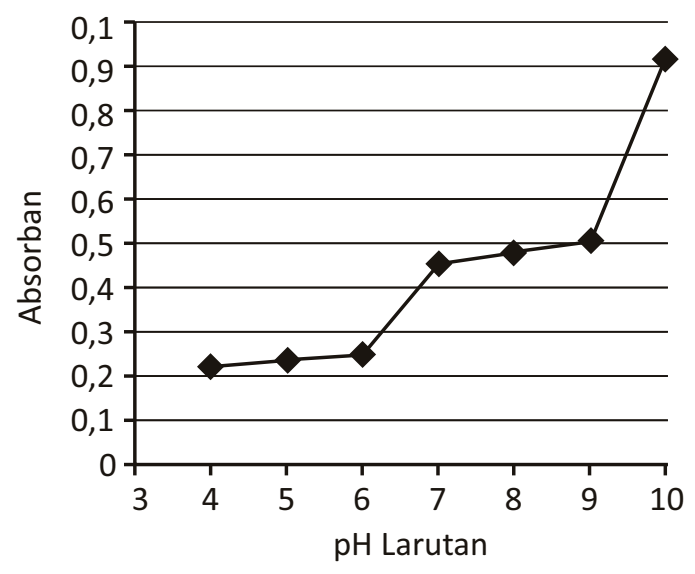

Gambar2. Pengaruh $\mathrm{pH}$ larutan pada ekstraksi klorofil daun pandan terhadap absorban (1 $\mathrm{g}$ daun pandan dan volume larutan 100 $\mathrm{mL})$.

$\mathrm{pH}$ larutan yang digunakan untuk menarik klorofil dari daun pandan divariasikan dari 4 hingga 10 . Pada $\mathrm{pH}$ sekitar 4 sampai 6 terlihat bahwa absorban larutan masih kecil, berarti bahwa konsentrasi zat warna klorofil yang terdapat dalam larutan masih rendah. Namun pada $\mathrm{pH}$ besar dari 6 terlihat peningkatan absorban, sehingga $\mathrm{pH} 10$ dianggap sebagai $\mathrm{pH}$ optimum, dan juga setelah dilakukan penyimpanan setelah 1 hari tidak terjadi penggumpalan. $\mathrm{pH}$ optimal ekstraksi klorofil dari daun pandan pada $\mathrm{pH} 10$, pengerjaan selanjutnya dilakukan pada $\mathrm{pH}$ optimum. Penelitian sebelumnya pada isolasi bixin pada biji kesumba menunjukkan bahwa bixin memiliki kecendrungan lebih stabil pada pH 4 (Suparmi \& Limantara, 2008). 


\section{Kestabilan Zat Warna}

Pengaruh Pemanasan Dengan Menggunakan $\alpha$ Tocoferol dan Dekstrin

Pengaruh pemanasan cahaya matahari terhadap absorban zat warna kunyit dan daun pandan dengan kondisi pemanasan selama 1 jam dengan variasi pemakaian dekstrin dapat dilihat pada Gambar 3.

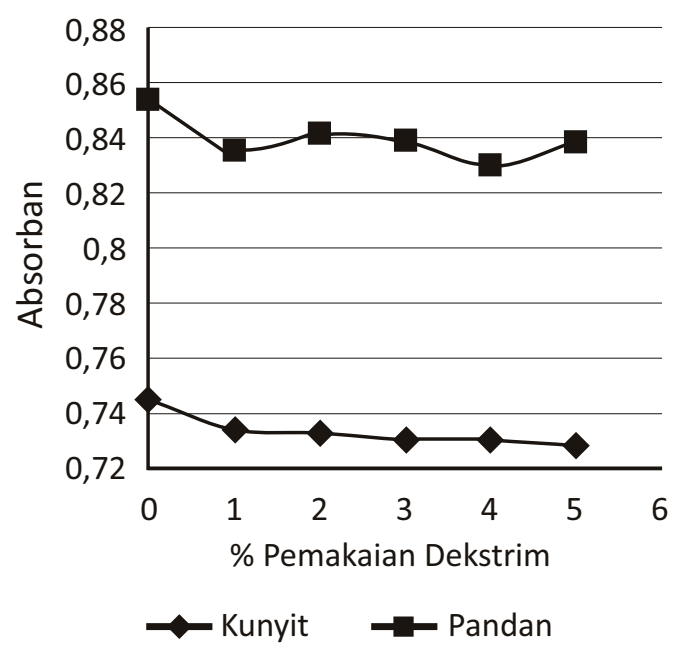

Gambar 3. Pengaruh pemanasan dengan menggunakan $\alpha$ tocoferol dan dekstrin terhadap absorban zat warna

Pada Gambar 3 terlihat bahwa zat warna pada pemakaian $0 \%$ dekstrin (tanpa dekstrin) tidak stabil terhadap paparan cahaya matahari. Hal ini dapat dilihat dari nilai Absorban yang kecil dibanding zat warna dengan pemakaian dekstrin. Pemakaian dekstrin 1-3\% terlihat kenaikan nilai absorban. Dekstrin mampu mengikat zat warna sehingga dengan pengaruh cahaya matahari tidak mempengaruhi nilai absorban. Firdausni dan Yeni (2012) menyatakan pemakaian $\alpha$ tocoferol dan dekstrin pada ekstrak cassiavera memberikan kestabilan yang baik terhadap pengaruh panas dan sinar Ultra Violet.

\section{Pengaruh lama penyimpanan terhadap kestabilan zat warna}

Pengaruh lama penyimpanan pada suhu kamar terhadap absorban zat warna kunyit dan daun pandan dengan kondisi pemanasan selama 1 jam pada berbagai variasi pemakaian dekstrin dapat dilihat pada Gambar 4 dan 5.

\section{Kurkumin dari kunyit}

Penyimpanan zat warna tanpa pemakaian dekstrin pada suhu kamar menyebabkan menurunnya absorban larutan. Semakin lama penyimpanan menyebabkan absorban larutan semakin menurun.

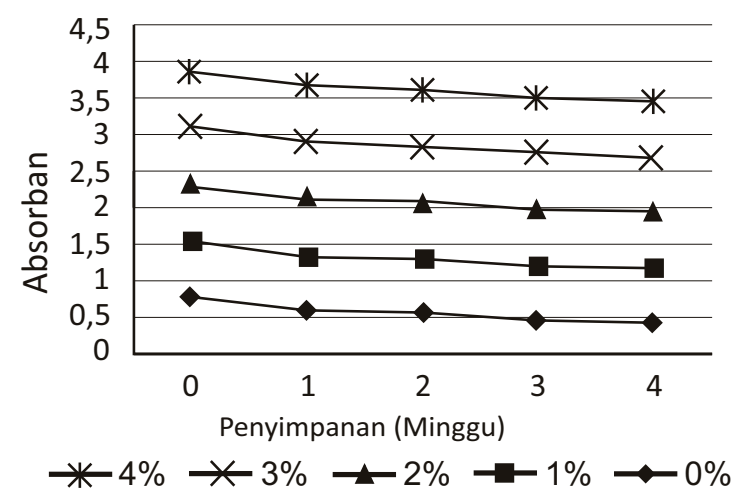

Gambar 4. Pengaruh lama penyimpanan dengan menggunakan $\alpha$ tocoferol dan dekstrin terhadap absorban zat warna kunyit

\section{Klorofil daun pandan}

Pengaruh penyimpanan zat warna pandan dengan kondisi pemanasan selama 1 jam pada berbagai variasi pemakaian dekstrin seperti pada Gambar 5.

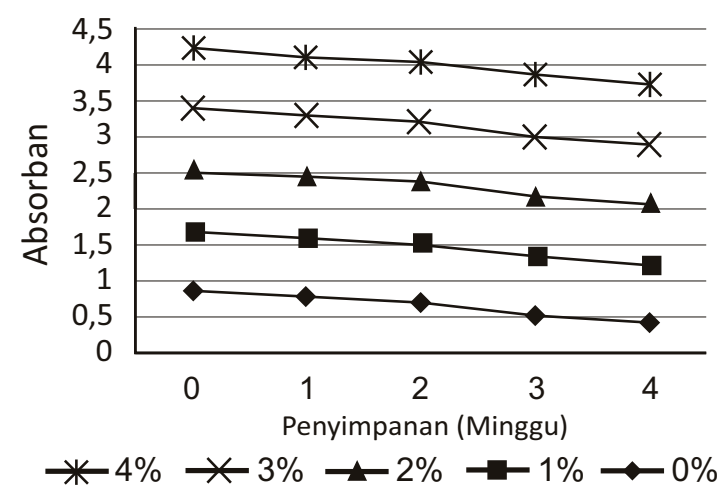

Gambar 5. Pengaruh penyimpanan dengan menggunakan $\alpha$ tocoferol dan dekstrin terhadap absorban zat warna daun pandan 
Pada penyimpanan selama 4 minggu penurunan absorban larutan zat warna mencapai sekitar $50 \%$. Penyimpanan zat warna dengan pemakaian dekstrin pada suhu kamar berpengaruh tidak nyata terhadap konsentrasi zat warna dalam larutan yang dapat dilihat dari nilai absorbannya yang hampir stabil.

\section{KESIMPULAN}

Berdasarkan hasil penelitian dapat disimpulkan bahwa nilai absorban dari ekstraksi zat warna kurkumin dari kunyit dipengaruhi $\mathrm{pH}$ larutan. $\mathrm{pH}$ larutan ekstraksi yang terbaik untuk kunyit adalah $\mathrm{pH} 4$ dengan suhu pemanasan $60^{\circ} \mathrm{C}$ (nilai Absorban mendekati ekstraksi kurkumin dengan alkohol 0,8539). Sedangkan untuk ekstraksi klorofil dari daun pandan $\mathrm{pH} 10$, sebagai pH optimum. Perlakuan pemanasan larutan zat warna kurkumin dan klorofil selama 1 jam berpengaruh tidak nyata terhadap konsentrasi zat warna dengan nilai absorbannya yang hampir stabil.

Dekstrin mampu mengikat zat warna dan meningkatkan kestabilan sehingga dengan pengaruh cahaya matahari tidak mempengaruhi nilai Absorban. Pada penyimpanan selama 4 minggu penurunan absorban larutan zat warna mencapai sekitar $50 \%$. Penyimpanan zat warna dengan menggunakan $\alpha$ tokoferol $1 \%$ dan dekstrin pada suhu kamar tidak begitu mempengaruhi konsentrasi zat warna dalam larutan yang dapat dilihat dari nilai absorbannya yang hampir stabil.

\section{DAFTAR PUSTAKA}

Altunbas, A., Lee, S. J., Rajasekaran, S. A., Schneider, J. P., \& Pochan, D. J. 2011. Encapsulation of curcumin in selfassembling peptide hydrogels as injectable drug delivery vehicles. Biomaterials, Journal. biomaterials.

Elizarni, Firdausni, Anwar, H., dan Sari, R. 2007. Studi penggunaan catechin dari gambir sebagai antioksidan alami dan butylated hydroxyanisole (BHA) sebagai antioksidan sintetis bagi bahan pangan (Rendang).
Firdausni dan Yeni, G. 2012. Prospek pengembangan zat warna alam dari cassiavera. Prosiding Seminar Nasional ReSaTek Ke-2. Padang, 14 November 2012.ISSN :2087-2526.

Kristina, Nova N, 2005. Peluang peningkatan kadar kurkumin pada tanaman kunyit dan tamulawak.

Limantara, L., P. Rahayu. 2008. Pigmen alami berbasis sumber daya lokal (dalam kualitas dan ketahanan pangan), Prosiding Seminar Nasional Pengembangan Agroindustri Berbasis Sumberdaya Lokal Untuk Mendukung Ketahanan Nasional, ISBN 978-9791366-28-1, 37-49.

Maulana, Ryan, 2012. Efektivitas penggunaan jenis pelarut dan asam dalam proses ekstraksi pigmen antosianin kelopak bunga rosella (Hibiscus sabdariffa L). Jurnal Teknologi \& Industri Pertanian Indonesia.

Melawaty, L., \& Makassar, U. K. I. P. 2009. Ekstraksi pigmen antosianin paprika merah (Capsicum anuum) dengan menggunakan asam tartarat. Sumber, 9,81 .

Niu, Y., Ke, D., Yang, Q., Wang, X., Chen, Z., An, X., \& Shen, W. 2012. Temperaturedependent stability and DPPH scavenging activity of liposomal curcumin at $\mathrm{pH}$ 7.0. Food Chemistry, $135,1377-1382$. doi:10.1016/j.foodchem.2012.06.018.

Pedro, L.L, Leticia LM, Luis IMR, Katarzyna W, Kazimierz W, and Judith A.H. 1997. Extraction of sunset yellow and tartrazine by ion-pair formation with adogen-464 and their simultaneous determination by bivariate calibration and derivative spectrophotometry.

Setyaningrum,N., 2010. Efektivitas penggunaan jenis asam dalam proses ekstraksi pigmen antosianin kulit manggis (Garcinia mangostana I.) dengan penambahan aseton $60 \%$. Kanisius. 
Sharma,R.A., A.j Gesher, W.P Stewar. 2005. Curcumin : The story so far. Europian journal of cancer 41 .

Suparmi, B., Prasetyo, L. Limantara. 2008. Kandungan dan isolasi pigmen pada selaput biji kesumba (Bixa Orellana L.) potensinya sebagai pewarna alami makanan, Prosiding Seminar Nasional Pengembangan Agroindustri Berbasis Sumberdaya Lokal Untuk Mendukung Ketahanan Nasional, ISBN 978-9791366-28-1, 55-69.

Titihalawa, S., F. S. Rondonuwu, H. Semangun. 2010. Efek penambahan kapur sirih terhadap kandungan klorofil dalam daun singkong (Manihot Esculenta Crantz). Prosiding Seminar Nasional Pengembangan Agroindustri Berbasis Sumberdaya Lokal Untuk Mendukung Ketahanan Nasional, ISBN 978-979-1366-28-1, 89-98.

Tonnesen,H.H., Grislingaas,A.L., \& Karlsen, J. 1991. Studies on curcumin and curcuminoids-XIX. Evaluation of thinlayer chromatography as method for Quantitation of curcumin and curcuminoids. Zeitschrift Lebensmittel - Untersuchung und - Forschung 193, 548-550
Winarni, S. Sarofa, O., dan Anggrahini, D. 2008. Ekstraksi dan stabilitas warna ubi jalar ungu (Ipomoea batatas L.,) sebagai pewarna alami. Jurnal Teknik Kimia, Vol. 3 No. 1.

Wibisono,Y., 2012. Perancangan iklan layanan masyarakat tentang bahaya pewarna sintetis pada makanan bagi anak sekolah di Semarang. Skripsi, Fakultas IImu Komputer.

Yeni, G., Zarlis, Firdausni, Anova, I. T., Syafri, M., Diza, Y. H., dan Afrizon. 2008. Stabilisasi ekstrak pewarna alam sebagai bahan tambahan makanan. $\begin{array}{lllllllllll} & 0 & m & u & n & i & k & a & s & i\end{array}$ No.238.DP/BPPI/Baristand/XII/2008.

Yusmeiarti, Firdausni, Hermianti, W., Failisnur dan Silfia.1997. Pengaruh penambahan campuran $\mathrm{BHA}$ asam askorbat dan BHT asam askorbat terhadap daya simpan rendang. Buletin BIPD Volume V No.2 edisi Juni, 21-29. 